Walisongo: Jurnal Penelitian Sosial Keagamaan

Vol. 28 No. 1 (2020) pp. 107-120

DOI: $10.21580 /$ ws.28.1.5562

\title{
Transmitting the Turāth: A Portrait of Islamic Tradition in the North Coast of Java in Countering Radicalism
}

\author{
Agus Irfan, ${ }^{1 *}$ Toha Maksum, ${ }^{2}$ Ahmad Mujib, ${ }^{3}$ Muna Yastuti Madrah ${ }^{4}$ \\ 1,2,3 Faculty of Islamic Studies Universitas Islam Sultan Agung, Semarang, Indonesia
}

\begin{abstract}
This article discusses one of the important Islamic traditions in the coastal areas of Central Java, Indonesia, where the majority of Muslims receive moral teachings through the recitation of turāth from the local islamic clerics, known as Kiai. This form of Islamic tradition is represented by Pengajian Ahad Pagi in Semarang and Jamaah Muji Nabi (often abbreviated as Jamuna) in Demak Regency. Examining religious movements through a phenomenological approach, this study found that in delivering the religious materials both Pengajian Ahad Pagi and Jamaah Muji Nabi use the transmission method. Such an approach emphasizes the aspect of narration, in which the Kiai reads one of the turāth (classical Islamic books), interprets it word by word, and then explains it comprehensively. Besides, the educational style delivered by the Kiai in the two said turāth-based teachings emphasized the aspect of Sufism that involved sense. It stands to reason that the congregation feels motivated, both in terms of religious knowledge and morals, and is possibly not trapped in a binary mindset seeing religious issues in black and white as framed by the radical groups. The findings of this study indicate that Pengajian Ahad Pagi and Jamaah Muji Nabi found the continuity of their vision and initial idea in response to the culture and life of the surrounding community.
\end{abstract}

Artikel ini membahas tentang salah satu tradisi penting dalam Islam di wilayah pesisir Jawa Tengah, Indonesia, di mana mayoritas umat Islam menerima ajaran moral melalui pembacaan kitab turāth dari islamic clerics setempat, atau yang dikenal dengan sebutan Kiai. Jenis tradisi Islam ini direpresentasikan oleh Pengajian Ahad Pagi di

*Corresponding Author: Agus Irfan (agus.irfan@unissula.ac.id), UNISSULA Semarang, Jln. Kaligawe Km. 4, Semarang, Indonesia 50112

ISSN 0852-7172 (p) 2461-064X (e)

(C) 2020 by the Authors, published by Walisongo: Jurnal Penelitian Sosial Keagamaan https://journal.walisongo.ac.id/index.php/walisongo 
Semarang dan Jamaah Muji Nabi (sering disingkat Jamuna) di Kabupaten Demak. Penelitian yang menelaah gerakan keagamaan melalui pendekatan fenomenologis ini menemukan bahwa dalam penyampaian materi keagamaan, baik Pengajian Ahad Pagi ataupun Jamaah Muji Nabi menggunakan metode transmisi. Pendekatan demikian ini menekankan aspek narasi, di mana Kiai membaca salah satu turāth (kitab-kitab Islam klasik), menafsirkannya kata demi kata, dan kemudian menjelaskannya secara komprehensif. Selain itu, gaya pendidikan yang dibawakan oleh para Kiai dalam dua pengajian berbasis kitab turāth tersebut juga menekankan pada aspek tasawuf yang melibatkan rasa. Oleh karenanya, cukup masuk akal kiranya jemaah merasa termotivasi, baik dari segi ilmu agama maupun akblak, dan tidak terjebak dalam pola pikir biner yang melihat isu-isu agama secara hitam-putih sebagaimana yang biasa dibingkai oleh kelompok radikal. Temuan penelitian ini menunjukkan babwa Pengajian Ahad Pagi dan Jamaah Muji Nabi menemukan kesinambungan visi dan gagasan awal mereka dalam merespon budaya dan kehidupan masyarakat sekitar.

Keywords: coastal islamic tradition; turāth transmission; counter radicalism

\section{Introduction}

Research on the transmission of turāth and its potential as a counter to the radicalism can be categorized as a portrait of Islamic tradition or Islamic life in a particular community (Zuhri, 2018, p. 1). Portraits of living Islam by some people can be interpreted as Living Quran and Living Hadith which is realized in the form of a process of community interaction to the Quran. It is not only limited to the meaning of the text but also emphasized the aspects of the application of Qur'anic texts in everyday life (Junaedi, 2015, p. 169; Syamsuddin, 2007, p. xiv). There were so many efforts to make the Quran and Hadith "down to earth".

In Java, the Islamic clerics using the pegon script to teach the Quran. Pegon is understood as the Javanese language that is written in the Arabic text (Hadi, 1995 in Choeroni et al., 2019) so the broader community can read it. Anthoni H Johns calls this local discussion process "vernacular" (Saenong, 2006, p. 579). In addition to literacy, other forms of Living 
Quran are several portraits of Islamic tradition represented through religious movements in coastal areas such as the Sunday Morning Recitation in Semarang City, held in the al-Itqān Islamic Boarding School area in Bugen Village, and Jamaah Muji Nabi recitation activities (hereinafter: JAMUNA) which were held in the area of Pesantren Girikusumo, Banyumeneng, Mranggen, Demak Regency.

In coastal communities, Islam's practice is carried out dynamically, commonly as religious values blended into a cultural form. Islam in the coastal area represents the relationship between Islam and the local culture, they become one entity. If there is a conflict between the Islamic values and the local culture it can be suggested as a common impact in the stretch of Islamic history. An example is the relationship between the legal aspect and mystical dimensions, symbols and substance, physical and mental meanings in the Islamic cultural discourses. Islam in coastal can be read as a natural variant and has the right to be present as if Indian Islam, Persian Islam, and so on (Salim, 2004, p. vi-vii, Woodward, 2010 p. 3). Cultural involvement needs to understand the area's context as da'wah's object was commonly carried out by islamic clerics in the past by involving aspects of esotericism and local wisdom.

One example of the coastal islamic clerics from Semarang City who always involves esoteric perspectives (Sufism) and local wisdom in conveying religious messages to the public is Kiai Sholeh Darat. He used to use the pegon script as the language of communication and becomes his literary vision. He realized that his target audience is the ordinary Muslims around Java. Ordinary muslims meant the Javanese people who are already integrated with the Islamic culture/values and they practice Islam that articulated in culture or vice versa. Kiai Sholeh Darat often touches on local customary issues as examples of cases such as giving offerings for ancestral spirits, earth alms tradition, calculating the lucky day using the Javanese calendar to avoid unfortunate things, festivity, and so on (Irfan, 2017, p. 104-107). 
The involvement of esoteric and exoteric aspects is always side by side and becomes the character of Islam's development in the coastal area of Java. In religious teaching activities, both are taught simultaneously trough formal teaching systems such as the pesantren (the Islamic boarding school) curriculum and in the informal settings such as the recitation activities held by islamic clerics (Javanese: Kiai) from time to time. In coastal areas of Java island like in Semarang City and Demak Regency, two religious activities, namely the Sunday Morning Recitation led by Kiai Haris Shodaqoh and JAMUNA Recitation which was led by Kiai Munif Zuhri always involved these esoteric aspects. At the Sunday morning recitation, Kiai Haris read the Al-Hikām by Ibn 'Ațāillāh alSakandārī. Before that, he read the Tafsīr Al-Ibrìz by Kiai Bisri Mustofa. While at the JAMUNA recitation, Kiai Munif always inserts Sufism morality material for contemplation on every Hadith in the Sahịịh Bukhārī book that is read and at the Maulid Dibāt event every Thursday night.

In these two recitations, both Islamic clerics teaches thematic issues as well as the Sufism. The congregation who participates in the activity does not only teach about Sharia but also accompanied by the material on morals for soul purification (tazkiyat al-nafs). As a result, the recitation congregation does not only learn about the exoteric issues or jurisprudence that discuss halal and haram or see problems in black and white. This binary paradigm has the potential to generate thought tensions that can lead to truth claims and lead to true feelings (megalomania) by negating other opinions. Such claims of truth have also become seeds of radical thoughts and actions that are carried out in the name of religion and have even sacrificed the human side as the main vision of the religious practice.

This article uses qualitative descriptive analysis with a socioanthropological approach. The anthropological approach is intended as an effort to understand religion by seeing the form of practice that grows and develops in society (Nata, 2000, p. 35). In this case, the form of 
religious practice referred to the Sunday Morning Recitation at the AlItqān Islamic Boarding School in Bugen Village, Bangetayu, Semarang City, and JAMUNA Recitation at the Girikusumo Islamic Boarding School, Mranggen, Demak Regency. We considered as religious movements in the Javanese coastal area. Both represented the living Islam which is fairly well-established. The Sunday morning recitation by Kyai Haris and JAMUNA by Kyai Munif has long historical roots, having both hard (mosques/pesantren) or soft (ideas/ideas) civilization, the two recitations above are also a long-living tradition. The three main elements of Islamic tradition described on Figure 1.

\section{Tradition}

Teks/Ideas

History

Figure 1.

The main element of Islamic tradition (Sources: Zuhri, 2018)

\section{The Transmission of Method}

The Sunday Morning and JAMUNA recitation learning models can be said as the traditional method. A transmission method is an approach that emphasizes the narrative aspect. Such approach praxis becomes a learning model for Islamic boarding schools, namely "bandongan" means reading one of the turāth books by interpreting one word to the next word to get a comprehensive explanation and added with the Sufism perspective. The thousands of recitation congregations felt motivated both from the aspect of knowledge and their religion's moral aspect, which was the initial goal both for Sunday morning recitation by Kyai Haris and JAMUNA by Kyai Munif Zuhri. The Sunday morning recitation and the JAMUNA emerged 
as a response to the social and cultural context around the community illiterate in religious knowledge and moral values.

In the contemporary context, the Sunday morning recitation and the JAMUNA found their momentum amid the love of some people, especially millennial groups, to learn religion instantly without going through the transmission process. In general, the millennial generation most likes to learn religion through online media. It potentially generated radicalism movements, both in the political sense and in the sense of religion, or to borrow Oliver Roy's term as the activist groups who see in Islam as much a political ideology as a religion (Hakim, 2005, p. v).

Such concerns are based on the fact that some of the suspected terrorist groups recently arrested by the police are millennials. Their involvement in the radicalism movement cannot be separated from the steps of terrorist networks that use social media to recruit new members and spread the content of radicalism. According to Linda Schlegel (2018, p. 3), at least two factors explain why radicalization is so massive through online media. First, the young generation's involvement is digital natives because they make social media their main communication. Second, the echo chamber on social media means that account owners will be treated to context according to what they like.

Along with that, BNPT's research in the last three years states that some students at State Universities in Java and Sulawesi have been exposed to radicalism in the stages of thinking and attitudes. They instantly receive this understanding, rooted in a rigid interpretation of religious dogma, and puts it into practice in discussions in intra-campus recognized organizations. Although the BNPT found the issue began 30 years ago, technology is massively amplifying it in the digital era as it is today. Radical agents do not have to meet their targets or hold discussions to agitate them. The propaganda of radicalism is sufficient to attract potential victims to Telegram and WhatsApp groups, then brainwash them with misleading ideologies (Riana, 2018). 
The findings of the BNPT above are supported by the latest data from the Setara Institute, which among the findings states that in various state campuses, discourse and exclusive religious movements are still developing and being intensified by several Islamic groups such as the Salafi-Wahabi movement, the Tarbiyah movement, and the potential Tahrīrìyah movement is a threat to Pancasila, democracy and the sustainability of the Republic of Indonesia (Halili, 2019). For them, Islam is a final and absolute guide that cannot be touched by the relative logic of human interpretation.

Recognizing this phenomenon, it is important to make the tradition of religious learning using traditional patterns more massive. This method can be a counter-discourse and attitude towards the instant religious learning process. With an approach that emphasizes soul education accompanied by religious practice as part of the internalization of values as well as the recitation of shalawat (praising the prophet of Muhammad Saw) and istighätsah (praying to the God for certain purposes), will form an individual more tolerant. This learning pattern is commonly practiced in almost all recitations in coastal areas, especially Sunday morning recitation in Semarang City and JAMUNA in Demak Regency. The ceremonial character of their recitation can be characterized as reciting tawasul (an effort to be closer to God) and istighāsah, tahlīl (praising the God by saying the sentence there is no god but Allah frequently) and reciting the maulid of the Prophet $/ D i b \bar{a}^{\prime}$. Such traditions are considered as bid' ah by Salafi groups.

In the case of the Sunday morning recitation, Kiai Haris chose two turāth books to read each week, namely the Kitab al-Hikàm by Ibn 'Ațāillāh al-Sakandārī after reading the Tafsìr al-Ibrīz by Kiai Bisri Mustofa. With the Bandongan approach, Kiai Haris recited verse by verse accompanied by an explanation of the verse's meaning before finally being contextualized with people's daily lives. Kiai Haris admitted that by 
reading the two books, many people felt enlightened and aware of their Islamic attitudes (Haris Shodaqoh, interview, 2020).

Meanwhile, in the case of Kiai Munif Zuhri's JAMUNA recitation, the book read was Sahīh Bukhārí. Some people suspect that the choice of Șahịh Bukhārī to be read consistently is merely seeking blessings (tabarrukan) and continuing the habits of predecessor scholars among Nahdlatul Islamic clerics (tafā'ulan). However, other opinions consider sacredness as the reason for reading the book (Syairazi, interview, 2020). However, as Murshid Tarīqah of the Naqsabandīyah Khālidìyah, the researcher considers that the Sabīh Bukhāri book was chosen, to emphasize that the Hadith materials are actually full of Sufism values and therefore the scholars of Hadith are a group of Sufis (Sufism practitioners). In the aspect of the faith, this affirmation is important to counter the impression that dichotomized the principle of faith between the Abl al-Hadits and al-Ash 'ârī or al-Māturìd $\bar{\imath}$ groups. The two groups' creed is considered as opposed to one another. Meanwhile, if it is traced carefully, the majority of Hadith scholars are followers of the al-Ash'ārī or al-Māturīdī faith (al-Azhārī, 2020, p. 283-284).

Technically, there is no differentiation method of Kyai Haris and Kyai Munif Zuhri. Kiai Haris in the Sunday Morning Recitation using the "bandongan" system as the pesantren learning model. However, in JAMUNA recitation, Kiai Munif recited the Hadith for about 10 minutes and took no more than one sheet. The rest of the time, he used it to explain the meaning of the Hadith by making the Prophet Muhammad as a role model as well as the moral ideal of the Hadith before finally being contextualized with the local life of the Javanese coastal community (Syairazi, interview, 2020).

\section{Sufism Education and Counter Radicalism}

The narrative method practiced both in the Sunday Morning Recitation and the JAMUNA recitation in the Javanese coastal area can become a counteraction against the truth claims of radical groups. The 
radical group, often claimed that the other groups are not following pure Islamic teachings. Urban Muslims commonly voice such characters. It is generally characterized by being anti-mazhab (lā madhhabīyah), easy to disobey other groups, forbidding tawasul and pilgrimages of the Prophet, forbidding the celebration of the Prophet's birthday / Dibā', punishing infidels and hell on the Prophet's parents, and so on.

In the area of action, this radical group that often calls themselves as Salafis. There are characterized as follows. First, the feeling of exaggeration in seeing other groups, especially non-Muslims such as Jews, Christians, and communists. They believe that the other group is conspiring to attack Muslims at any time so that they feel they are living in an atmosphere of war. Second, it is obligatory to fight against the other groups above which consist of non-Muslim groups (al-kuffär al-mulā'in) and secular Islamic groups (al-murtaddīn al-fäsiqīn) which are considered reluctant to apply God's law as written in the text (Jum'ah, 2013, p. 10-11).

Since the dangers of radicalism thinking are latent against the perpetrators and the surrounding community and the next generation, collective awareness is needed as a counter to cultural radicalism through the following steps. First, studying and teaching the Ash'ārīyah creed as a school of a creed with a moderate character and is adhered to by most Muslims. Second, studying and introducing the four schools of fiqh (Ḥanafī, Mālikī, Shāfi'ī, and Ḥanbālī) adhered to by the Ablus Sunnab wal Jamáah group without closing the door to ijtihad. Including, in this case, it does not deny the jurisprudence of other schools, even from the Shi'ah fiqh group. Third, studying and introducing morals through Sufism. The process of Sufism teachings lead to the heart cleanness from animalistic nature (takhallī) to be filled with positive things (tahallī), finally, all human senses focus on one point, God (tajallī) (Jum‘ah, 2013. p. 14-15).

The ideas proclaimed by Alī Jum'ah above are in line with Sunday Morning Recitation and JAMUNA recitation. For Javanese coastal communities who are predominantly Sunni-oriented, the trilogy of Ablus 
Sunnah wal Jamā'ah which includes faith, jurisprudence, and Sufism has become a daily understanding and behavior. This Aswaja trilogy is manifested from the dialectic of externalization, objectivation, and ends in the internalization process or subjective awareness in the form of the different experiences of each congregation after participating in religious learning at the recitation.

Salahuddin Shodaqoh, the younger brother of Kiai Haris, said that the style of education delivered by Kiai Haris through this Sunday Morning Recitation emphasizes the heart or soul aspect as is usually taught by Kiai in many Islamic boarding schools (pesantren). Since heart or soul education, there will be many events and teachings that are supra-rational and unreasonable. This heart education will at least involve the sensitivity of taste and blessings (Salahuddin Shodaqoh, interview, 2020). Therefore, the results of the output of the recitation on Sunday morning will only be felt by the congregation.

One of the Sunday Morning Recitation congregations, Giyanto (42 years), admitted that he had experienced many attitude changes after attending the Sunday morning recitation led by Kiai Haris Shodaqoh. He said that he had been a member of this Sunday morning recitation congregation since 2014. He felt the religious guidance. He considers himself to come from the dark history of life. In his view, Kiai Haris is considered capable of explaining the relationship between sharia and nature (Giyanto, interview, 2020). In line with Giyanto is the opinion expressed by Aryo Agus (52 years), another Sunday morning recitation congregation from Port Housing. He said that being active in the Sunday morning recitation was because Kiai Haris was able to bridge his worries in understanding Islamic knowledge. Before, he acted in one of the religious organizations to teach an extreme understanding of Islam (Aryo Agus, interview, 2020). Kiai Haris tried to connect the Islam teachings, soul, and attitude through reading the al-Hikàm Book. 
Meanwhile, Kiai Munif, at the JAMUNA recitation, even though he did not read Sufism directly, read Hadith, explaining the meaning of Hadith that was conveyed by Kiai Munif was full of Sufism reflections. Kiai Munif tried to sound the Hadith's meaning as material for his contemplation of processing the sensitivity of taste. He tried to linkage the Prophet's behavior in the contemporary context, especially through the morals displayed by Islamic clerics in Javanese coastal areas.

One of the JAMUNA recitation congregations, Ahmad Syairazi, said that the Sufi commentary delivered by Kiai Munif was very clear compared to the lexical explanation of the sounds of the Hadith. Because they try to make Hadith as material for reflection, it is as if the Hadith that is read is nothing more than an entrance for self-reflection. Unlike the Sufism education by Kiai Haris, which departs from the text, Sufism's explanation from Kiai Munif seems to be more pronounced and unified even though what is read is the Hadith text (Syairazi, interview, 2020).

Sufism education, both in the Sunday Morning Recitation and JAMUNA recitation as Javanese coastal pattern is a distinction from urban patterns. The style of religious studies of urban groups tends to be textual and often revolves around exoteric issues. The negation of esoteric or Sufism reading is because they consider this approach a new thing that does not have an epistemic background in Islam. Therefore, the paradigm that is formed becomes binary and sees problems in black and white. They found it easier to judge other groups as deviant by creating dichotomous terms such as salaf - bid' ah. A term that has the potential to divide the harmony of Muslim society (ukhūwah). This anti-difference mindset has become the source of the radicalism movement which demands a single and absolute interpretation.

In contrast to the moderate character represented by the Ablus Sunnah wal Jamā'ah group, the radical groups can be characterized by an intolerant attitude toward the freedom of a person's civil and political rights (Irfan, 2019 , p. 238). Another feature of radical Islamic action is the application of 
sharia law as a single legal system in the state structure and assessing țāghūt against state policymakers who do not heed Islamic law (Achilov \& Sen, 2017, pp. 11-17). The framework of ideological differences between moderate politics and radical politics, as written by Dilshod Achilov and Sedat Sen (2017), is seen in Figure 2.

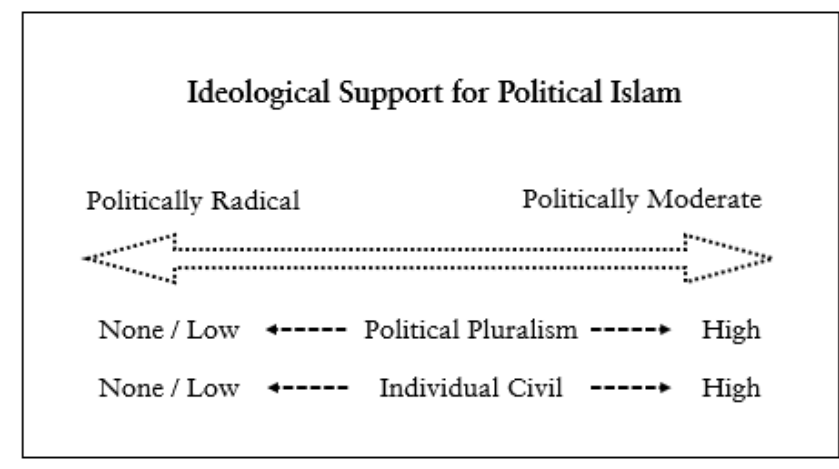

Figure 2.

Difference between Moderate and Radical Politics.

Sources: Dilshod Achilov dan Sedat Sen (2017)

\section{Conclusion}

As a religious movement with historical roots with a massive number of congregations, both the Sunday Morning Recitation and the JAMUNA recitation use the wise learning model. The two recitations preserve the transmission method by reading the turāth book as the habit for Islamic boarding schools by reading from one word to the next, which is continued by explaining comprehensively and adding the Sufism perspective. Both the education of Sufism in the Sunday morning recitation and the JAMUNA recitation became the main intake by making the text read as an entry point for self-reflection.

Apart from using the narrative method and adding the perspective of Sufism, the second recitation model is also characterized by the education of value internalization through the reading of the Maulid Diba $\bar{a}^{\prime}$ and istighätsah. This Javanese coastal learning tradition that involves the soul 
is also a distinction of the Salafi group's religious movements that are commonly carried out by urban Muslims in urban areas. This religious pattern is quite loved by millennial groups who learn religion instantly through online media without going through the transmission process.

The style of religious studies of urban groups tends to be textual and often revolves around exoteric issues. Its religious character can be characterized by an anti-mazhab (lā madhhabìyah) view, easy to denounce other groups, forbidding tawasul and pilgrimages of the Prophet, forbidding the celebration of the Prophet's birthday / Diba $\bar{a}^{\prime}$, and so on. The paradigm that is formed becomes binary by looking at problems only in black and white. The Salafi found it easier to judge other groups as deviant by creating dichotomous terms such as salaf - bid' ah. This antidifference mindset has become the seed for the radicalism movement which demands a single and absolute interpretation.[w]

\section{References}

Achilov, D., \& Sen, S. (2017). Got political Islam? Are politically moderate Muslims really different from radicals? International Political Science Review, 38(5), 608-624. https://doi.org/ 10.1177/0192512116641940

Al-Azhārī, U. (2020). Aqīdah al-Muhaddithīna waṣilatuhum bi alTașawwuf. In Mu'tamar al-Shīshān: Abhāats man hum Abl alSunnah wa al-Jamāa'ah (pp. 281-311). Oman: Dār al-Nūr alMubīn.

Choeroni, C., Madrah, M. Y., \& Aziz, A. (2019). Pegon as Indigenous and the Cultural Confrontation (18-19 century). Adab-International Conference on Information and Cultural Sciences, 147-163.

Hakim, L. (2005). Kata Pengantar. In R. Sihbudi \& E. Turmudzi (Eds.), Islam dan Radikalisme di Indonesia (p. v). Jakarta: LIPI.

Halili, H. (2019, May 31). Wacana dan Gerakan Keagamaan di Kalangan Mahasiswa: Memetakan Ancaman atas Negara Pancasila di Perguruan Tinggi Negeri. Setara Institute for Democration and Peace. https://setara-institute.org/wacana-dan-gerakan-keagamaandi-kalangan-mahasiswa-2/ 
Irfan, A. (2017). Local Wisdom dalam Pemikiran Kyai Sholeh Darat: Telaah terhadap Kitab Fiqh Majmu'at al-Shari'ah al-Kafiyah li al'Awam. Ulul Albab: Jurnal Studi dan Penelitian Hukum Islam, 1(1), 88-109. https://doi.org/10.30659/jua.v1i1.2224

Irfan, A. (2019). Nalar Pemikiran Etika Politik A. Mustofa Bisri (Perspektif Maqāșid al-Siyāsah). Universitas Islam Negeri Sunan Ampel.

Jum'ah, A. (2013). Al-Mutashaddidūn: Manhajuhum wa Munāqashat Ahammu Qad̄āyāhum (ke-5). Cairo: Dār al-Muqațtam.

Junaedi, D. (2015). Living Qur'an: Sebuah Pendekatan Baru dalam Kajian al-Qur'ān. Journal of Qur'an and Hadits Studies, 4(2), 169-190. https://doi.org/10.1548/quhas.v4i2.2392

Nata, A. (2000). Metodologi Studi Islam. Jakarta: Raja Grafindo.

Riana, F. (2018, June 7). Cegah Paham Radikal, Jejak Digital Media Sosial Mahasiswa Dilacak. Nasional.Tempo.Co.

Saenong, F. F. (2006). Vernacularization of the Qur"an: Tantangan dan Prospek Tafsir al-Qur"an di Indonesia. Jurnal Studi Al-Qur'an, 1(3), 579.

Salim, H. (2004). Konstruksi Islam Jawa dan "Suara yang Lain.” In Islam Jawa: Kesalehan Normatif dan Kebatinan (pp. v-xi). Yogyakarta: LKiS.

Schlegel, L. (2018). Online-Radicalization: Myth or Reality. Konrad Adenauer Stiftung - Fact \& Finding.

Syamsuddin, S. (2007). Ranah-ranah Penelitian dalam Studi al-Qur'an dan Hadits. In S. Syamsuddin (Ed.), Metode Penelitian Living Qur'an dan Hadits (p. xiv). Yogyakarta: Teras.

Woodward, M. (2010). Java, Indonesia and Islam. Netherlands: Springer. https://doi.org/10.1007/978-94-007-0056-7

Zuhri, H. (2018). Living Islam: Apa dan Mau ke Mana? Living Islam: Journal of Islamic Discourses, 1(1), 1. https://doi.org/10.14421/ lijid.v1i1.1530 